\title{
CREATIVE ETHNICITY: MUSIC AS AN ELEMENT OF ETHNICITY AMONG POLISH TATARS
}

\author{
Urszula ABŁAŻEWICZ-GÓRNICKA iD, Karolina RADŁOWSKA (D) * \\ Institute of Sociology, University of Białystok, Plac NZS 1, 15-420 Białystok, Poland
}

Received 23 March 2020; accepted 21 April 2021

\begin{abstract}
The aim of this article is to analyse the role of ethnic music in the life of the Tatar minority in Poland as an example of creative ethnicity. On the one hand, modern Tatar musical practices construct an interesting example of "invented tradition" because the studied group does not have "musical memory", while on the other hand, these activities are aimed at the group's future. Music can fulfill different social functions. In the case of ethnic groups, three of these functions seem to be particularly relevant: integrational, political (ideological) and identity. Desk research reveals the formal and informal musical practices undertaken by Polish Tatars. The values and musical assets associated with Tatar culture reflect the minority's identity. The main statement of the article is that music is an important element that contributes to constructing the contemporary group's identity. Tatar music is becoming an essential element of Tatar culture, enhancing a sense of the group's distinctiveness. The contemporary Tatar music groups construct a significant Tatar showcase to the audience outside of the Tatar ethnic group, as well as form an important identity element of the Tatar community and a manifestation of creative ethnicity. It is also possible to find correlations between their repertoire and contemporary group transformations, including those related to its identity.
\end{abstract}

Keywords: creative ethnicity, ethnic identity, ethnic music, Islam, Muslims in Poland, Podlasie, Polish Tatars.

\section{Introduction}

The cultural heritage of certain ethnic groups is one of the most significant elements constructing their ethnic identity and is the key element allowing them to survive. Anderson (2016) underlines the fact of ethnic groups being in fact cultural groups. A distinctive culture not only differentiates minority groups from the dominant group, but it is also an important integrating factor within these groups. It is a distinctive culture that allows ethnic communities to be given the status of an ethnic, regional or national group; it is related to being granted certain privileges or being refused them. That is why, according to Nowicka:

*Corresponding author. E-mail: k.radlowska@uwb.edu.pl

Copyright (c) 2021 The Author(s). Published by Vilnius Gediminas Technical University

This is an Open Access article distributed under the terms of the Creative Commons Attribution License (http://creativecommons. org/licenses/by/4.0/), which permits unrestricted use, distribution, and reproduction in any medium, provided the original author and source are credited. 
"Culture and cultural distinctiveness not only have become an autotelic value, but is also a recognized and respected argument. Ethnic culture, being distinctive from other cultures, is both aa reason for pride and a weapon to struggle for various rights and privileges by ethnic communities" (2009, p. 13).

Ethnicity can be analysed from many different perspectives. However, the constructionist approach seems to be the most useful concept since it emphasizes the contemporary transformations of ethnic groups. As Nagel states:

"Ethnicity is constructed out of material of language, religion, culture, appearance, ancestry, or regionality. The location and meaning of particular ethnic boundaries are continuously negotiated, revised, and revitalized, both by ethnic group members themselves as well as by outside observers" (1994, pp. 152-153).

In that sense, ethnicity is a dynamic and complex social phenomenon, encompassing creative adaptation, creation, and re-creation of various cultural elements. Moreover, as a result of globalization, cultural heritage within ethnic groups becomes the subject of reflection and consequently a subject of creative modifications. Ethnic groups concentrate on preserving rather than strictly following the tradition, so they tend to accept the "invention of tradition" (Hobsbawm \& Ranger, 2003). This phenomenon is also an example of creative ethnicity.

Although relations between the culture of society treated as a whole and minority groups are usually located within cultural dominance, minority culture does not have to be considered merely as the one opposing dominant culture; minority culture may also contribute to developing what is considered to be universal culture within the society (Wadowski, 2005, pp. 24-27). It may enrich the cultural mainstream, proving its multicultural nature. According to Wadowski:
"[...] these elements are used very superficially, considering only selected parts of mi- nority culture, certain remains of folklore, customs, attire, rather decorative elements. The function of these elements in a dominant culture is also rather decorative, they do not disturb its main core (as it is becoming more and more blurred) neither do they enrich dominant culture significantly" (2005, pp. 25-26).

Here, we have to mention the phenomenon of ethnic marketing, the response from the dominant group to certain products offered by minority groups (J. L. Comaroff \& J. Comaroff, 2009). Thought of as "ethnicity for sale", these are cultural goods presented at local festivals and fairs that are attractive for both the local community and tourists, which recall the idea of "tamed exoticism". Central, regional and local authorities support these events since they promote "multiculturalism" and are evidence that their regions are perceived of as open and attractive places.

Ethnic groups who do not reside in their own states find cultural distinctiveness particularly significant, as it becomes instrumental in helping them gain particular political benefits (Nowicka, 2009, p. 14). The small community of Polish Tatars is an example of this type of group, as they do not reside in their own state and are thus classified as an ethnic group in the Polish legal system.

Polish Tatars, also referred to as Lithuanian Tatars, are a small ethnic group of almost 3000 people residing mainly in the Podlaskie Voivodeship, Poland, as well as the Pomeranian Voivodeship, Poland, Masovian Voivodeship, Poland and Lower Silesian Voivodeship, 
Poland. Polish Tatars are Sunni Muslims and are a minority among other Muslim communities. Recently, the community's approach to their cultural heritage has become rather "flexible", although it is one of the basic symbols together with religion and descent (Radłowska, 2018).

At present, there are two Tatar music groups: Tatarski Zespół Dziecięco-Młodzieżowy "Buńczuk" and Tatarski Zespół Taneczno-Wokalny "Buńczuk". They perform Tatar showcases to non-Tatar audiences, as well as form an important identity element of the Tatar community. It is also possible to find correlations between their repertoire and contemporary group transformations, including those related to identity.

While analyzing the phenomena related to minority music culture, we believe it includes both formal and informal activities regarding music and certain values and traditions. These activities reflect a minority's identity and its approach to the dominant group as well as other ethnic communities. This definition includes various forms of musical expression - instrumental music, songs, dances and other more or less formal patterns. We believe that music is mainly a social activity, referring to the "musicking" concept presented by Small:

"The essence of music lies not in music works but in taking part in performance, in social action. Music is thus not so much a noun as a verb, 'to music'. To music is to take part in any capacity in a musical performance, and the meaning of musicking lies in the relations that are established between the participants by the performance" (1998, p. 9).

Our publication presents Polish Tatars' musical activities performed by the music groups mentioned above.

\section{Towards the concept of creative ethnicity}

Among the keys words that describe the complexity of the modern ethnically diverse world, the category of ethnicity has a particular importance. Therefore, a brief analysis of ethnicity should precede further considerations. Although the etymology of ethnicity goes back to ancient Greece, its present understanding comes only from the beginning of the 1970s and was closely related to the change in American sociology and the paradigm of assimilation (Hutchinson \& Smith, 1996, p. 4). This new category explained new phenomena such as: social and political change, identity construction, race relations, social conflict, the formation of nations, the emergence of ethnic diversity, and the idea of multiculturalism (Sokołowskij \& Tiszkow, 2008).

Despite the extensive use of this term describing a wide range of ethnic phenomena, ethnicity remains a complex and difficult to define concept. Grzegorz Babiński, an outstanding sociologist of ethnicity in Poland, identified four meanings of the term ethnicity as follows: a set of objective and/or conscious features of an ethnic group; a type of ethnic identification; a social movement; or a kind of primordial bond. However, it should be emphasized that the distinguished approaches do not have to be, as the author himself notes, treated separately. In many cases, they complement each other, showing the complexity of the ethnicity (Babiński, 1998). Although it is difficult to define what ethnicity is, it is much easier to indicate its features. According to Babiński the features of ethnicity are variety, multidimensionality, contextuality and gradualness. 
There are several theoretical approaches to ethnicity and various classifications of this phenomenon. It can be said that primordial and constructive theories constitute opposite views on ethnicity. The first concerns a specific type of biological (van der Berghe, 1987; Shils, 1957) or cultural (Geertz, 2005, pp. 294-295) bonds that make up groups. The constructive approach emphasizes the symbolic and situational importance of ethnicity. Since the concept of creative ethnicity is closely interconnected to the latter perspective, it will be discussed more deeply.

According to constructivism, ethnicity is a response to the specific needs of a group and is used to meet those needs (Gellner, 1983; Anderson, 2016; Barth, 1998). In this approach, ethnicity is viewed as a dynamic phenomenon and responds to changes in the contemporary world. In other words, the constructive perspective draws attention not only to the hybrid identity of ethnic groups but also to their situational nature. Since the constructivist position is not homogeneous, the instrumentalist approach can be distinguished within it. This perspective assumes that ethnic groups are actually groups of interests that arise in order to obtain certain benefits through the mobilization of co-ethnics. A special role in this process falls to the leaders who are the authors of specific action strategies. In this approach, cultural heritage plays a symbolic meaning and becomes an important tool to achieve certain goals. Hence, the significant role of invented tradition (Hobsbawm \& Ranger, 2003).

While previous work emphasized the groups' past, i.e. the role of tradition and cultural heritage, it should be stressed that modern ethnic groups constantly create and re-create their image in an attempt to maintain, mark, or change their position in society. Moreover, contemporary research on ethnic groups reveal the diverse or even conflicting in-group strategies, cultural aims and self-images, reflecting the fluidity and complexity of group identities in late modernity.

Modern identities are dynamic and situational. However, as Nowak points out, "The flexible identity does not indicate its inconsistency, but reproduction in order to maintain the constancy" (2008, p. 90). Groups construct their image on the basis of elements that are contextually relevant. In other words, ethnic groups balance between different visions of ethnic culture. It is particularly significant on the borderlands, due to the hybrid identities of its inhabitants.

Creative ethnicity reflects the aforementioned processes. It is used to emphasize the dynamic, flexible character of modern ethnic culture and identification. Ethnic creativity assumes that ethnic groups can draw from various sources to create and/or re-create their own culture. What these resources will be and what elements depends on the situation of the group and its relationship with other ethnic groups (inspirations, borrowings, comparisons). From this point of view, it does not matter whether the group uses elements of its own culture or constructs them. Moreover, this account of ethnicity stresses the agency of the members of the ethnic community:

"By emphasizing some traditions while downplaying others, and by combining various traditions, styles, and interpretations of ethnicity, ethnic men and women take greater control of their lives. They come to play active roles in determining what cultural features are relevant to their understandings of ethnicity. In turn, the proliferation of these flexible and 'hybrid' traditions makes it easier for ethnics to choose how and why they relate to their ethnicity" (Stern, 1991, xiv). 
Practically, creative ethnicity can be understood as group strategies aimed at creating desirable internal (self-image) and external (inter-group relations) ethnic identification through the selective usage of traditional and non-traditional cultural elements. In this context, it is worth referring to the concept of rewarded ethnicity. It states that some members of the group may benefit from representing the group externally. However, the image of the group they present must be consistent with the strategy set by the leaders. Rewards play a key role in supporting those activities, especially in mobilizing the younger generation (Nowak, 2008, p. 94). The example of ethnic music groups discussed in this article can be seen as an interesting example of this phenomenon.

\section{Music as a part of minority culture: ethnic music and its functions}

According to Jabłońska (2014, pp. 31-44), there are thirteen basic functions that music performs in a society: aesthetic, communicative, educational, integrational, identity-related, expressive, entertainment, utilitarian, therapeutic, mobilizational, political, religious and economic. When analyzing minority group culture, identity-related, integrational, and political functions need to be recognized as the most significant.

Music contributes to making, marking and maintaining cultural distinctiveness within cultural minorities. Ethnic music constructs its specificity in its sound, rhythm, structure, forms, instruments, attire, language, and the importance of music in daily life. Dahlig, Polish ethno-musicologist, believes that the purpose of music created by minority groups is to blur style differences, to combine secular and religious music, to unite traditional and modern music, singing and instrumental music, acting and dance. He concludes: "Expression is the essence, emphasizing nationality/spirituality" (Dahlig, 2014, pp. 212-213).

Not only does music culture express itself in the forms being used, its relation with identity is enhanced by the group's emotions. The analysis of ethnic or national minorities' music shows there are certain differences in expression and professionalization levels among the groups representing particular religious, ethnic or national minorities (see Dahlig, 2014). As was already mentioned, cultural distinctiveness based on music could be treated as "cultural goods", as economic value. This area of minorities' cultural activism seems to be the subject of some of their debates and arguments.

The integrational functions carried out by minority music could be analyzed within the group as well as within the larger community. Ethnic groups and music events contribute to building and maintaining social relations and communication, both among individuals and families within a particular ethnic community. Music also contributes to building relations among various minority organizations. Performances of ethnic groups are also a simple way to present their culture to other social groups, although these cross-cultural contacts are often criticized as so called "boutique multiculturalism" (Fish, 1997). Dahlig recapitulates the bidirectional nature of minority music projects:

"The internal version, undertaken so as to protect the community, co-exists with the constructed expressions aimed at those observing them and the friendly connoisseurs. Popularization is planned, though; it presents the content that the minority members want to show, yet it does not reflect the whole truth. Perhaps, when the debate on both 
internal and external structures related to certain activities is harmonized, it will result in an accurate interpretation of ethnic minorities' music culture. Simultaneously, there is neither a national nor religious minority who is resistant to the influence of the dominant group. [...] It is the effect of conscious or unconscious assimilation, resulting from the sequence of generations at peace" (2014, pp. 214-215).

Considering an in-group perspective, ethnic groups constitute important agendas of socialization and social control. Moreover, artistic groups within ethnic minorities might be regarded both as a form of cultural education (demonstrating significant cultural content) and civic education (developing social competences in order to increase a certain level of social activism). Music contributes to constructing the space necessary to form local/regional identity in culturally diverse areas.

Martiniello and Lafleur indicate a political dimension related to minority music. Although their analysis refers to popular music, we believe that the political perspective carried by traditional music allows for a better understanding of the dynamic nature of minority cultural heritage and tradition being reconstructed. This context allows us to analyze the decisions of artistic groups such as their name, the language of their performance, the environment of the events, musical characteristics such as rhythm and tonality, attire and decorations. Minority groups create their image and position in the wider community through artistic activities (Martiniello \& Lafleur, 2008, pp. 1195-1199).

The functions presented above allow for an analysis of ethnic music as the capital owned by minority groups. Sociologically, capital means "[...] all the measures used in order to achieve certain goals and values, constructing the particular aims for groups and individuals; the aims that are internalized and institutionalized - to a certain extent", when the supplies, being considered capital, can be converted, multiplied and exchanged to other forms of capital (Drozdowski \& Ziółkowski, 1999, pp. 11, 13). Ethnic music is one of the elements, which builds social and cultural supplies within minority communities. Social capital refers to the values resulting from social ties, both those based on similarities of social traits (bonding social capital) and networks overcoming socio-cultural differences (bridging social capital). Music integration as a function is directly related to the process of building social resources of the group. Cultural capital, in a socio-economic perspective, is an asset providing a cultural value together with economic values (Throsby, 2011, p. 51). Cultural capital defined in this manner might occur both in a material and non-material form. It is a social perception that is a decisive factor while indicating the direction and range of a possible conversion of cultural resources.

\section{Tatar minority's music culture in Poland as an example of creative ethnicity}

The discussion about Tatar ethnic music should begin with a statement that there is no preserved musical tradition in the Polish Tatar community - there is no "music memory" within this group. Rather, contemporary Tatar music activities form an interesting example of "invented tradition". Barbara Pawlic-Miśkiewicz declares:

"When we say 'music traditions', it is rather an illusive notion, as Polish Tatars did not elaborate their own distinctive style in music, nor did they cherish any traditional 
tunes. They also did not use any instruments characteristic among Tatars from Bashkiria, Tatarstan or Crimea" (2016, p. 1).

To understand Polish Tatar both historically and in the present day, it is important to refer to two periods- the period of the Second Polish Republic (1918-1945) and the post-war period. During the inter-war period, the Muslim world in Poland constructed its essential institutions during a period of religious and ethnic revival and, as several authors believe, started forming its modern ethnic identity (Wendland, 2013). Nevertheless, it should be emphasized that neither at that time nor earlier did this group have any musical traditions. According to Miśkiewicz, the repertoire of the few Tatar bands that existed at that time was nearly limited to Polish folk songs and dances, and only sometimes included Crimean and Volga region music in their repertoire (2001, p. 7).

When analyzing Tatar cultural life during the interwar period, Miśkiewicz points out the fact that Tatar balls ${ }^{1}$ and other events were not very different from similar Polish occasions: "People danced to the most popular music of the epoch; dancing waltz, polka and oberek was simply a must" (Kamocki \& Miśkiewicz, 2001, p. 148). However, there are no detailed sources on this subject. The post-war period is marked by a lack of cultural activity among the group.

The World War II (WWII) and the post-war territorial evolution resulted in intense group changes. Since then, the community has had to function within three separate states: Lithuania, Belarus and Poland. Migrations, both those towards the West and towards the Białystok Voivodeship (1919-1939), Poland, contributed "to the end of a coherent Tatar world", as Warmińska, investigating the contemporary Tatar community, defined the situation (2016, pp. 92-93). Due to the political situation in post-war Poland, both religious and ethnic development of the group became delayed. Subject literature described the Tatar community as an ethnographic group, assimilated to the dominant Polish group.

The transformation period resulted in the ethno-cultural revival of the group. Tatar leaders succeed in initiating the first Tatar music group. The idea to create this group appeared much earlier, as during the celebrations commemorating 600 years of Tatar settlement in Poland, one of the Tatar community's leaders wrote in a Tatar periodical:

"In the 1970s Tadeusz Chachaj, the director of the Filharmony in Białystok, wanted to take care of these young people. When I presented the matter to the young people representing our community, they thought it was absurd. Some of them suggested we were mad" (Konopacki, 1999, p. 14).

Józef Konopacki justified his idea by the example of a similar Tatar group working in Kaunas, Lithuania, presenting it as an outstanding model. This idea was soon realized.

It is worth mentioning here that such a situation was possible due to the political changes in Poland, which revealed the existence of minority groups. It has to be added that the processes of invention and re-invention of tradition may be associated with political aims, not to mention the vison of the group's culture as maintained by ethnic leaders.

The first Tatar band in post-war Poland was the group "Buńczuk", founded in 1999. Halina Szahidewicz was the founder of the group. During the initial period, there were two

\footnotetext{
${ }^{1}$ During Tatar balls, organized usually during Ramazanski bajram, young Tatars met each other; these events thus contributed to maintaining the endogamous nature of the group.
} 
sections working: a declamation section and a vocal/dance section. During the initial period, 23 people formed the group, aged 6-19. They presented the first performance on 20th March, 1999 in Białystok, Poland, as a part of the "Podlasie Echoes" cycle, organized by the Provincial Centre of Culture Animation and the Historical Museum in Białystok. In 2000, a dancing section was formed and the group was finally called "Buńczuk" (Szahidewicz, 2015).

The name given to the group refers to a flagstaff, which was once a symbol of the 13th Wilno Uhlan Regiment, which was formed in 1920 and fought during WWII. In the preface to a book published on the 15th anniversary of the group being founded, Miśkiewicz, mufti of the Republic of Poland and head of the Highest Muslim Board of Muslim Religious Union (MRU) in Poland, wrote:

"Our 'Bunczuk' is a cultural phenomenon, regaining and reconstructing the lost heritage, or - in other words - allowing us to assimilate the values brought by Tatar dance and music. Allowing us to add Tatar culture to both Polish and Tatar heritage" (Szahidewicz, 2015, p. 5).

Łyszczarz, in his article on the importance of the group's activities so as to cultivate Tatar identity, affirms that "not only did the founder of the group intend to establish an artistic institution, she also created a platform to integrate the ethnic community, the space to allow young people to meet their tradition" (2015, p. 73). Szahidewicz herself admits to having been "forced" to present her work with the group in the public sphere by culture activists, municipal authorities, and minority leaders (Bunczuk.eu, 2020).

Initially, the group's repertoire was based on Polish romantic poetry referring to oriental themes of Adam Mickiewicz and Juliusz Słowacki, regional poetry of Jan Leończuk, Wiesław Kazanecki and Marta Cywińska as well as Tatar authors as Stanisław Kryczyński, Selim Chazbijewicz and Musa Çaxarxan Czachorowski. The combination of ethnic and regional threads was certainly an intentional act aiming to demonstrate ethnic Tatar traditions as being closely related to the Polish nation and the Tatars' own area in Podlasie (Radłowska, 2018, p. 170). Since Polish Tatars did not have their own repertoire, Szahidzewicz had to use Crimean Tatars' dance and musical traditions. Lewiza Bigbułatowa, a Crimean choreographer from Simferopol, Republic of Crimea, helped her to achieve her goals through running dance classes for children and youth. Since then, one of the versions of Crimean Tatar attire became the official stage costume of the group (Miśkiewicz, 2001). During the following years, another artist, Gizel Mamina, from Bashkortostan, Russia, helped the group extend their repertoire by using the musical and dance traditions of Bashkortostan and Tatarstan, Russia. In 2011-2012, a Chechen choreographer living in Białystok named Achmed Tashaev taught traditional dancing within his workshops.

Since the moment it was founded, "Buńczuk" performed both in events prepared for their ethnic community and in the events, festivals, presentations and conferences where they were watched by broader audiences. "Bunczuk" also performs in schools in Białystok and could be considered an educational activity.

The first major problem that Szahidewicz had to face was an exodus of group members. The first members of the group decided to quit after they graduated from university. It was then when the concept of the group was reconstructed to be mainly composed of school age and preschool children (Łyszczarz, 2015, p. 75). In 2013, the group was divided into two separate groups, connected with the split in the MRU. The "old" group functions as Tatarski Zespół Dziecięco-Młodzieżowy "Buńczuk”, whereas the "new” formation as Tatarski Zespół 
Taneczno-Wokalny "Buńczuk". Since the split, two different repertoire models have been elaborated, reflecting two inner kinds of identity transformation.

The original "Buńczuk" maintained its amateur nature. Szahidewicz emphasizes the fact of all children, regardless of their potential, being accepted in the group:

\begin{abstract}
"This amateur nature of the group was never considered a problem by any organizations or associations that invited them to take part in the events. They supported us, as they realized that what we do we do it well. It happened that all our salaries and prizes were donated to these in need, so practically we worked and performed as if we did charity work" (2015, p. 67).
\end{abstract}

The first members of "Buńczuk" are now engaged in all the tasks related to the group's activities, including working as instructors.

Tatarski Zespół Taneczno-Wokalny "Buńczuk", working within the Tatar Cultural Association Foundation (TCAF), accepted another style similar to other dance formations in Białystok. It co-operates with professional dance and vocalist instructors ${ }^{2}$. Such instructors, such as choreographer Tashaev (a founder of Lowzar - a traditional Chechen children's troupe), choreographer Svetlana Savastsyan (classical and modern dance instructor) and vocal instructor Barbara Kornacka, teach dance and vocal classes (Bunczuk.pl, 2018).

The two groups are different if we focus on the level of professionalism related to the traditional music as presented by the author of "Musical Traditions of National Minorities in Poland" (Dahlig, 2014) in the book Report on the State of Traditional Music Culture. Grozdew-Kołacińska, while analyzing the changes in folklore music, points out:
"[...] it is the stage (festivals, concerts) and the media (radio and Internet) as well as music publications that construct the natural environment for folklore. This shift in- creased the aesthetic function that folklore has always served, though not in such a great scale" (2014, p. 43).

Certain changes occurring in the environment are also essential- the younger generation is more and more interested in singing and dancing and there are more and more artistic institutions educating children and teenagers, so the result of this tendency is the more professional nature of amateur dance circles.

There are various recruitment strategies applied in the groups. According to the regulations, "Buńczuk" in the TCAF recruits children, teenagers and adults of Tatar descent or coming from mixed Tatar families (Bunczuk.pl, 2018). Children from a non-Tatar environment can participate in the "Buńczuk" promoted by the MRU and in all the projects it coordinates (Szahidewicz, 2015, p. 36). Both groups participate actively in artistic events in Białystok, the region, other places in Poland, and abroad.

\title{
4. Tatar music and its importance
}

When analyzing the role and importance of Tatar music in this particular groups' life, we can conclude that there are three functions it holds: integrational, ideological and identityrelated. It needs to be stressed that these functions are closely related.

\footnotetext{
2 In the anniversary concert on 21 December, 2019, professional musicians accompanied the artists.
} 
The integrational music aspect might be analyzed both from internal and external perspectives. Regular rehearsals and tournées enhance group coherence and ties. The integrational process occurs both in peer groups and between other generations. It contributes to constructing a family-like atmosphere in the group and integrating members of the community, strengthening its structure. One of the former group members says:

"I remember our classes taking place in one of schools in Białystok, kids rehearsed and the parents, every Sunday after RE lessons, brought traditional home-made cakes. This day, the only day a week, "Buńczuk" rehearsals after the religion lesson made us realize we are doing a good thing for our community" (Szahidewicz, 2015, p. 45).

Being a member of the group might be regarded as an instrument used in order to form various socio-cultural competences, such as the unique experience of performing in public, the ability to co-operate with others, as well as broader social competences resulting from being a member of a social association (ethnic organizations, including artistic groups, are the elements of civic society). People working for ethnic organizations need particular skills, like receiving and settling the expenditures from grants as well as co-operating with other cultural and public institutions.

"Buńczuk" performs during events considered important for the Tatar community, organized by the leading organizations within the group. Thus, not only is participating in the group a mechanism of including the younger generation in the minority community and building a sense of ethnic pride, it is also a form of cultural education aimed both to the ethnic group and to the dominant group. During festivals, the audience learns about the history of the group as well as its contemporary life, including ethnic culture. Participating in festivals and similar events, which attracts numerous groups, allows the exchange of certain key information, which is significant in the minority perspective.

While constructing their artistic image, groups make their distinctiveness more "homey". These types of narration often apply the concept of Tatar patriotism as being a significant factor while fighting for Polish independence. Tatar dances and the workshops teaching them is another element that contributes to the integration process with the dominant group. Tatar commitment to "polishness" is emphasized both by the repertoire and by combining Polish with Tatar languages, particularly noticeable in the group working within the MRU. Cicha, the vocalist who recorded a compact disc with Tatar music in 2011, recalled her investigations of Polish Tatars' musical heritage, concluding: "[...] I was sure the anthology should include lyrics written in Polish. As it is the language Polish Tatars have been speaking for several centuries. The language that expresses their sorrow" (2016, p. 105).

Not only is the integrational aspect important while selecting the repertoire, it is also the ethnic identity that is demonstrated in the content by the Tatar community of Poland on the local, regional, national, and sometimes international levels. Both the content and the artistic form serve certain group interests. These are the group leaders, who politicized ethnicity, creating a "desirable" image of their community. Considering the group working within the MRU, their repertoire highlights the group's close relation to Podlasie as their home through the use of poems written by poets from Podlasie, or to the Polish nation with poems written by Polish bards. Children reciting the surahs of the Quran demonstrate the significance given to religion 
by the group leaders. The other group emphasizes its strong ties with the tradition and culture of Tatar peoples as a basic trait of its distinctiveness. ${ }^{3}$

Both groups, although they were founded as a consequence of group conflict, use the same original name "Buńczuk". It indicates two important aspects: they consider themselves the legal successors of "the original" "Buńczuk", as well as expressing the emotional aspect of the name as a reflection of Tatar patriotism and loyalty to their "foster motherland." It is also related to another function of the group- an identity function.

Numerous publications have analyzed Tatar identity (Kryczyński, 1938; Jasiewicz, 1980; Warmińska-Zygmunt, 1999; Łyszczarz, 2013; Radłowska, 2018). Until the 1990s, it was mainly the debate: Do Tatars form a group assimilated to Polish society or are they rather a distinctive ethnic/national community? According to one scientific research, the group's identity is a complex subject. In her opinion, it is based on three distinctive axes: ethnic (being Tatar), religious (being Muslim) and national (being Polish) (Warmińska-Zygmunt, 1999). Nearly two decades later, while analyzing the group's identification, Karolina Radłowska noted numerous changes, both those referred to as outside transformations and those related to transformations within the group as being the factors transforming Tatar identity from an identity based on religion to an ethno-cultural identity. Contemporary ethno-cultural group identification is mainly based on descent criteria. It is externalized by strong primordial ties and the emotional group approach to symbolic resources, including culture. It contributes to group consolidation (Radłowska, 2018).

The processes presented above reveal the reasons why the groups were constructed and focus on their repertoire, related to the traditions of Tatar peoples. Applying the elements of other cultures is aimed at extending cultural resources by including elements from the "outside" sphere. The aim is to focus on the ethnic distinctiveness of the group as being different from the Polish group as well as other minority groups (Belarusian, Lithuanian, Romanian, Ukrainian).

\section{Conclusions}

The aim of the article was to present the processes of (re)creating music culture as an important element of Tatar identity and show music as an element of the creative ethnicity of the group. The authors focused on the multi-aspect importance of Tatar music as well as the artistic music groups in relation to contemporary transformations within the group. Our analysis demonstrated the fact of music being an important element contributing to constructing the contemporary group's identity. At present, Tatar music is becoming an essential element of Tatar culture, enhancing the sense of the group's distinctiveness. "Buńczuk" and its history reflect the minority's efforts to develop their own music. Cicha insists: "Tatars do need to have their own music [...] and there is some gap, a certain space that needs to be filled" (2016, p. 103).

\footnotetext{
3 This strategy of repertoire selection might indicate the policy to present the group to the outside through a marketing of ethnicity, referring to those elements of Polish Tatar culture that might be attractive to the audience.
} 
The musical practices of Polish Tatars represent an interesting example of creative ethnicity. Tatar music groups follow the general traits of contemporary Tatar culture that, quite selectively, refer to tradition while concurrently creating new cultural phenomena. Selectivity means opting consciously for those elements that in the leaders' opinion could become group symbols, recognized by other groups. These are such elements such as Tatar cuisine or the Tatar yurt. Constructing new social phenomena is achieved by attributing new cultural forms, often borrowed from other Tatar groups, with an ancient veneer. Sabantuy, the festival of the plough, serves as a perfect example of this type of action (Radłowska, 2018). Warmińska, a sociologist, mentions the process of regaining Tatar lost tradition. In her opinion:

"25 years of observing ethnic life in Polish Tatars group proves gradual regaining of their cultural resources. Being one of many minority groups in a postwar period, it lost the influence on the form and content of their own heritage. At present, their cultural traditions are being discovered and identified or organized more consciously, ethnicity-related places are being regained or created, global trends to present their ethnic culture are applied (commercial actions related to the heritage)" (Warmińska, 2016, p. 101).

The split within the group and the crisis resulting from this fact resulted in chaos and disintegration of the group. However, it also strengthened both formations being forced to intensify their work, competing with each other. The ideology and identity carried by both groups were constructed by Tatar political and social leaders, who are rarely undivided in their approach to the past and traditions of the group. As Nowak states:

"Considering the process of creating the ethnicity, they are involved in maintaining certain historical continuum, preventing the group from losing ties with their history, yet constructing new ethnic patterns and strategies. They perceive ethnicity as the space constructed with varied and competitive positions and standpoints, expressed by various organizations, parties, movements or leaders, representing the minority towards the environment. [...] Even in the minority groups being clearly defined and identified, they play a particular game to be legitimized to represent the group" (2008, pp. 92-93).

Regardless of the group differences mentioned above, Tatar music, apart from its integrational and identification-related functions, integrates the group, both on an internal and national level. Not only does it enhance the sense of group distinctiveness and help to form Tatar ethnic pride, it also focuses on Tatar commitment to relations with the Polish nation. It conforms to the contemporary policy of promoting "multiculturalism" both on the provincial and national levels. This policy presents the "Polish Orient" as a kind of "homey" exoticism, and as an emblem of Podlasie and Poland.

\section{Note}

We would like to emphasize that the article is an attempt to analyse contemporary ethnic identity in the context of creativity. It is not our aim to present an exhaustive description of this concept, but to draw attention to its usefulness. 


\section{References}

Anderson, B. (2016). Imagined communities: Reflections on the origin and spread of nationalism. Verso.

Babiński, G. (1998). Etniczność. In Z. Bokszański \& A. V. I. Kojder (Ed.), Encyklopedia Socjologiczna (pp. 192-193). Oficyna Naukowa.

Barth, F. (1998). Ethnic groups and boundaries: The social organization of culture difference. Waveland Press.

Berghe, van der P. L. (1987). The ethnic phenomenon. Praeger.

Bunczuk.eu. (2020). “Buńczuk”. Tatarski Zespół Dziecięco-Młodzieżowy. http://bunczuk.eu/

Bunczuk.pl. (2018). Tatarski Zespół Taneczno-Wokalny Buńczuk. http://www.bunczuk.pl/

Cicha, K. (2016). Urwana nuta. Kontakt, 31, 102-105.

Comaroff, J. L., \& Comaroff, J. (2009). Ethnicity, Inc. University of Chicago Press. https://doi.org/10.7208/chicago/9780226114736.001.0001

Dahlig, P. (2014). Tradycje muzyczne mniejszości narodowych w Polsce. In W. Grozdew-Kołacińska (Ed.), Raport o stanie tradycyjnej kultury muzycznej (pp. 211-222). Instytut Muzyki i Tańca.

Drozdowski, R., \& Ziółkowski, M. (1999). Funkcjonowanie kapitałów kulturowego i społecznego w dobie pragmatyzacji świadomości społecznej. Przegląd Socjologiczny, 48(2), 11-37.

Fish, S. (1997). Boutique multiculturalism, or why liberals are incapable of thinking about hate speech. Critical Inquiry, 23(2), 378-395. https://doi.org/10.1086/448833

Geertz, C. (2005). Interpretacje kultur. Wybrane eseje. Wydawnictwo Uniwersytetu Jagiellońskiego.

Gellner, E. (1983). New perspectives on the past. Nations and Nationalism. C. Fasolt (General Ed.). Cornell University Press.

Grozdew-Kołacińska, W. (2014). Muzyka tradycyjna, śpiew tradycyjny, taniec tradycyjny, próba konfrontacji terminów z rzeczywistością zastaną. In W. Grozdew-Kołacińska (Ed.), Raport o stanie tradycyjnej kultury muzycznej (pp. 40-47). Instytut Muzyki i Tańca.

Hobsbawm, E., \& Ranger, T. (Eds.). (2003). The invention of tradition. Cambridge University Press.

Hutchinson, J., \& Smith, A. D. (1996). (Ed.). Oxford readers. Ethnicity. Oxford University Press.

Jabłońska, B. (2014). Wykłady z socjologii. Socjologia muzyki. Wydawnictwo Naukowe Scholar.

Jasiewicz, Z. (1980). Tatarzy polscy. Grupa etniczna czy etnograficzna? Lud, 64, 145-158.

Kamocki, J., \& Miśkiewicz, A. A. (2001). Tatarzy Słowiańszczyzna obłaskawieni. Universitas.

Konopacki, J. (1999). Tatarski węzeł. Życie Tatarskie, 3-4, 9-12.

Kryczyński, S. (1938). Tatarzy litewscy. Próba monografii historyczno-etnograficznej. Seria: Rocznik Tatarski. T. 3. Wydanie Rady Centralnej Związku Kulturalno-Oświatowego Tatarów Rzeczypospolitej Polskiej.

Łyszczarz, M. (2013). Młode pokolenie polskich Tatarów. Studium przemian generacyjnych młodzieży w kontekście religijności muzułmańskiej oraz tożsamości etnicznej. Katedra Socjologii Wydział Nauk Społecznych Uniwersytet Warmińsko-Mazurski.

Łyszczarz, M. (2015). Znaczenie młodzieżowego zespołu pieśni i tańca "Buńczuk" dla kultywowania tatarskiej tożsamości etnicznej. In M. Ickiewicz-Sawicka (Ed.), Kultura - naród - Etniczność na pograniczach Europy i świata (pp. 65-81). Stowarzyszenie Miłośników Kultury Ludowej.

Martiniello, M., \& Lafleur, J.-M. (2008). Ethnic minorities' cultural and artistic practices as forms of political expression: A review of the literature and a theoretical discussion on music. Journal of Ethnic and Migration Studies, 34(8), 1191-1215. https://doi.org/10.1080/13691830802364809

Miśkiewicz, A. (2001). Młodzieżowy Buńczuk. Białostocka Gazeta Wspótczesna, 159, 17-19. 
Nagel, J. (1994). Constructing ethnicity: Creating and recreating ethnic identity and culture. Social Problems, 41(1), 152-176. https://doi.org/10.2307/3096847

Nowak, J. (2008). Kreowanie etniczności w sytuacji zmian społecznych. In M. Lubaś \& G. Kubica (Eds.), Tworzenie i odtwarzanie kultury. Tradycja jako wymiar zmian społecznych (pp. 89-109). Wydawnictwo Uniwersytetu Jagiellońskiego.

Nowicka, E. (2009). Kulturowa odmienność w działaniu. Narody duże i małe, stare i nowe. In E. Nowicka (Ed.), Kulturowa odmienność w działaniu. Kultury i narody bez państwa (pp. 9-22). Zakład Wydawniczy Nomos.

Pawlic-Miśkiewicz, B. (2016). Tradycje muzyczne Tatarów polsko-litewskich. http://ansamblperegrinus. pl/uploads/artykuly/tradycje_muzyczne_tatarow_polsko_litewskich_dr_barbara_pawlic_miskiewicz.pdf

Radłowska, K. (2018). Tatarzy polscy. Ciagłość i zmiana. Fundacja Sąsiedzi.

Shils, E. (1957). Primordial, personal, sacred and civil ties: some particular observations on the relationships of sociological research and theory. The British Journal of Sociology, 8(2), 130-145. https://doi.org/10.2307/587365

Small, Ch. (1998). Musicking: The meanings of performing and listening. Wesleyan University Press.

Sokołowskij, S., \& Tiszkow, W. (2008). Etniczność. In A. Bernard \& J. Spencer (Ed.), Encyklopedia antropologii społeczno-kulturowej (Volumen 197). Oficyna Wydawnicza.

Stern, S. (1991). Introduction. In S. Stern \& J. A. Cicala (Eds.), Creative ethnicity: Symbols and strategies of contemporary ethnic life (xi-Xx). Utah State University Press. https://doi.org/10.1002/micr.1920120305

Szahidewicz, H. (2015). “Buńczuk”. 15 lat Tatarskiego Zespołu Dziecięco-Młodzieżowego. Muzułmański Związek Religijny w RP Muzułmańska Gmina Wyznaniowa w Białymstoku.

Throsby, D. (2011). Kultura się liczy. Ekonomia i kultura. Narodowe Centrum Kultury.

Wadowski, D. (2005). Więzi w grupach mniejszościowych a ich kultura. In L. Dyczewski (Ed.), Kultura grup mniejszościowych i marginalnych (pp. 17-28). Katolicki Uniwesytet Lubelski.

Warmińska, K. (2016). O "odzyskiwaniu” kultury etnicznej. Przykład polskich Tatarów. Przeglą Kulturoznawczy, 1(27), 91-103.

Warmińska-Zygmunt, K. (1999). Tatarzy polscy. Tożsamość religijna i etniczna. Towarzystwo Autorów i Wydawców Prac Naukowych "Universitas".

Wendland, W. (2013). Filozofia, psychologia, religia, socjologia, historia, polityka. "Trzy czoła proroków z matki obcej”. Myśl historyczna Tatarów polskich w II Rzeczypospolitej. Towarzystwo Autorów i Wydawców Prac Naukowych "Universitas". 